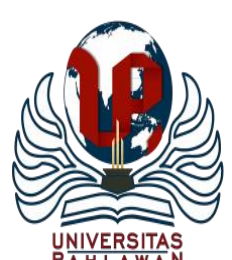

Jurnal Abdidas Volume 2 Nomor 6 Tahun 2021 Halaman 1418 - 1426

JURNAL ABDIDAS

http://abdidas.org/index.php/abdidas

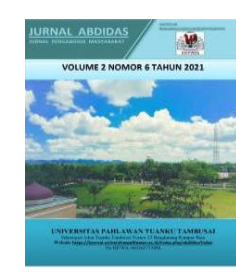

\title{
Sosialisasi Pentingnya Menumbuhkan Minat Baca di SD Negeri 236 Rumpala II Sinjai Barat
}

\author{
Nasrullah $^{1 凶}$, Irvan Muliyadi ${ }^{2}$, Touku Umar ${ }^{3}$, Agus Darmawan $M^{4}$ \\ lmu Perpustakaan, Universitas Islam Negeri Alauddin Makassar, Indonesia ${ }^{1,2,3,4}$ \\ E-mail : nasrullah.nasir@uin-alauddin.ac.id ${ }^{1}$ irvanmuliyadi71@gmail.com $^{2} \underline{\text { oemartouk11@gmail.com }}^{3}$ \\ agusdarmawanm@gmail.com ${ }^{4}$
}

\begin{abstract}
Abstrak
Membaca merupakan kegiatan proses memahami isi teks dengan bersuara atau dalam hati dan juga untuk menemukan berbagai informasi yang terdapat dalam tulisan. Kegiatan proses membaca menjadi salah satu jenis kemampuan berbahasa melalui tulisan yang bersifat reseptif karena dengan membaca seseorang akan memperoleh informasi, ilmu pengetahuan, dan pengalaman-pengalaman baru yang belum diketahui sebelumnya. Berdasarkan hal tersebut maka dilaksanakan kegiatan pengabdian kepada masyarakat di SD Negeri 236 Rumpala II Sinjai Barat dengan metode pemberian sumbangan koleksi bacaan, penyuluhan tentang pentingnya membaca serta pembinaan pengelolaan perpustakaan. Tujuan pengadian kepada masyarakat ini diharapkan siswa SD Negeri 236 Rumpala II Sinjai Barat lebih memahami pentingnya membaca serta pustakawan juga mampu mengelola perpustakaan dengan baik sehingga siswa lebih senang berkunjung ke perpustakaan. Hasil kegiatan pengabdian kepada masyararakat ini menunjukkan bahwa sosialisasi berjalan dengan lancar serta antusias siswa dalam menyimak materi juga sangat aktif, sehingga minat baca siswa SD Negeri 236 Rumpala II Sinjai Barat dan pengelolaan perpustakaan tentu akan lebih baik lagi.
\end{abstract}

Kata kunci: sosialisasi, membaca, minat baca

\section{Abstract}

Reading is a process of understanding the contents of the text aloud or in the heart and also to find various information contained in writing. Reading process activities are one type of language ability through receptive writing because by reading someone will gain information, knowledge, and new experiences that were not previously known. Based on this, community service activities were carried out at SD Negeri 236 Rumpala II West Sinjai with the method of providing reading collection donations, counseling about the importance of reading and fostering library management. The purpose of this community service is that it is hoped that students of SD Negeri 236 Rumpala II Sinjai Barat will better understand the importance of reading and librarians are also able to manage the library well so that students prefer to visit the library. The results of this community service activity showed that the socialization went smoothly and the enthusiasm of students in listening to the material was also very active, so that the reading interest of students at SD Negeri 236 Rumpala II West Sinjai and library management would certainly be better.

Keywords: socialization, reading, interest in reading

Copyright (c) 2021 Nasrullah, Irvan Muliyadi, Touku Umar, Agus Dermawan

$\triangle$ Corresponding author

Address : Universitas Islam Negeri Alauddin Makassar

Email : nasrullah.nasir@uin-alauddin.ac.id

ISSN 2721- 9224 (Media Cetak)

DOI $\quad$ : https://doi.org/10.31004/abdidas.v2i6.490

ISSN 2721- 9216 (Media Online) 


\section{PENDAHULUAN}

Di Indonesia kemampuan literasi sangatlah rendah dan memprihatinkan. Menurut Organization for Economic Cooperation and Development (OECD) melalui survey Programme for International Student Assessment (PISA) pada 2018, Indeks literasi remaja Indonesia berada di peringkat bawah dengan skor 371. Padahal ratarata skor literasi remaja di negara- negara anggota OECD telah berada di angka 487. Artinya, data tersebut menunjukan bahwa kesuksesan pemerintah dalam meluaskan pendidikan belum diimbangi dengan keberhasilan dalam menumbuhkan budaya dan minat baca masyarakat, sehingga tingkat literasi yang dimiliki oleh masyarakat Indonesia masih tergolong rendah dan perlunya upaya dalam menumbuhkan budaya dan minat baca tersebut (Kurniasari \& Arfa, 2020).

Minat baca masyarakat tergolong rendah jika dibandingkan dengan minat baca yang dimiliki oleh bangsa lain. UNDP (United Nations Development Program) tahun 2012 menyatakan bahwa indeks pembangunan manusia berdasarkan angka buta aksara posisi Indonesia berada pada urutan 111 dari 175 negara. Salah satu faktor penyebab rendahnya minat baca disebabkan oleh masih dominannya budaya tutur dibandingkan budaya baca. Selain itu, tidak meratanya penyebaran koleksi perpustakaan dan taman baca diberbagai lapisan masyarakat. serta belum optimalnya pemberdayaan. Hal ini menjadi dampak terhadap minat dan budaya baca masyarakat dalam mengembangkan dirinya (Maulana \& Dkk, 2019).

Sedangkan dari survey UNISCO menunjukan bahwa minat baca masyarakat yang paling rendah di ASEAN adalah Indonesia. Rendahnya minat baca dibuktikan dengan indeks membaca masyarakat mencapai $0,001 \%$ artinya dari seribu penduduk, hanya ada satu orang yang masih memiliki minat baca yang tinggi. Angka ini masih sangat jauh jika dibandingkan dengan angka minat baca di negara lain, misalnya, Singapura yang memiliki indeks membaca mencapai $0,45 \%$. Berdasarkan studi Most littered Nation In the World yang dilakukan oleh Central Connecticut State University pada Maret 2016 lalu, minat baca penduduk Indonesia menduduki peringkat 60 dari 61 negara. Minimnya minat baca yang dimiliki oleh bangsa Indonesia adalah persoalan yang sangat krusial, salah satu upaya yang dilakukan oleh pemerintah untuk meningkatkan kualitas layanan dan menumbuhkan minat baca yaitu membangun sebuah komunitas literasi di tengahtengah masyarakat (Munir \& Hidayatullah, 2019).

Minat merupakan kecenderungan untuk menyukai beberapa kegiatan. Jika seseorang berminat terhadap sesuatu maka dia akan mengikutinya dengan senang hati. Minat membaca adalah kekuatan yang mendorong anak untuk tertarik pada kegiatan membaca, sehingga keinginan membaca nya muncul dalam dirinya sendiri tanpa paksaan dari orang lain. Membaca adalah aktivitas yang telah diperkenalkan sejak usia dini. Melalui membaca, kemampuan berpikir manusia akan semakin terarah da $\mathrm{n}$ berkembang, ilmu pengetahun pun akan semakin luas dan dapat meningkatkan kualitas sumber daya manusia terutama diera digital. Oleh karena itu, membaca menjadi kebutuhan manusia agar mudah menghadapi tantangan dan persaingan dengan bangsa-bangsa lain di dunia. Jadi, Minat baca ialah 
1420 Sosialisasi Pentingnya Menumbuhkan Minat Baca di SD Negeri 236 Rumpala II Sinjai Barat Nasrullah, Irvan Muliyadi, Touku Umar, Agus Dermawan

DOI: https://doi.org/10.31004/abdidas.v2i6.490

keinginan yang kuat dalam diri seseorang untuk membaca agar apa yang dibaca dapat dipahami dan dapat menambah wawasan dan ilmu pengetahuan bagi diri seseorang (Nasrullah, 2020).

Minat baca merupakan hal yang dapat meunjang berkembangnya suatu Negara. Sedangkan budaya baca dapat meningkatkan pengetahuan masyarakat. Minat tidak begitu saja ada dalam diri seseorang melainkan timbul karena adanya pengalaman dan usaha untuk mengembangkanya. Minat pada dasarnya adalah penerimaan suatu hubungan antara diri sendiri dengan sesuatu dari lingkungan sekitar. Semakin kuat hubungan maka semakin kuat juga minat. Minat membaca selalu disertai keinginan dan usaha-usaha untuk membaca. Minat baca membutuhkan perhatian yang disertai perasaan senang terhadap kegiatan membaca. Minat baca yang di bangkitkan pada anak yang memasuki jenjang sekolah dasar dapat dijadikan landasan bagi berkembangnya budaya baca di masa depan. Kualitas membaca anak sangat berpengaruh terhadap keberhasilannya dalam belajar dan dalam kehidupanya (Maharani, 2017).

Pengembangan minat dan budaya baca masyarakat dilakukan dengan mendirikan komunitas literasi atau taman baca sebagai sarana pendidikan yang bertujuan untuk menumbuhkan minat baca dan budaya baca guna mewujudkan masyakat pembelajar sepanjang hayat. Untuk itu perlunya perluasan akses taman baca dan penguatan komunitas literasi sehingga dapat memberikan layanan yang lebih baik dan berkualitas terhadap masyarakat. Komunitas memiliki peran dalam penyebaran informasi kepada masyarakat sekitar, karena sebagian masyarakat belum mampu untuk memperoeh informasi dengan caranya sendiri. Komunitas literasi didirikan sebagai sarana publik yang dapat mendorong minat baca dan budaya baca guna menambah wawasan bagi masyarakat. Peran komunitas dalam menumbuhkan minat baca masyarakat yaitu dengan cara meyediakan koleksi dan fasilitas yang memadai bagi masyarakat sehingga masyarakat dapat memperoleh informasi yang dibutuhkan, karena ketersediaan koleksi akan berpengaruh pada minat baca masyarakat (Monica, 2020).

Kurangnya minat baca yang dimiliki oleh masyarakat Indonesia seharusnya mendorong pihak-pihak yang terkait untuk segera mungkin memfasilitasi dan menganalisis apa saja yang menjadi penyebab hal tersebut. Dalam hal ini, diperlukan kerjasama antara penulis, penerbit, dan pemerintah dalam pengadaan sumber bacaan. Pertama, penulis diperlukan untuk mencari informasi yang mampu menuangkan ide-ide dan pengetahuanya untuk disebarluaskan kepada masyarakat. Kedua, penerbit diperlukan memfasilitasi para penulis dalam mempublikasikan karya-karyanya. Ketiga, pemerintah sangat diperlukan untuk memberikan subsidi buku yang sangat dibutuhkan oleh masyarakat. Hal ini akan lebih baik jika pemerintah memberikan anggaran khusus bagi pembinaan perpustakaan. Selain perpustakaan komunitas literasi juga dapat memberikan pelayanan pendidikan kepada masyarakat. dengan keberadaannya tersebut, komunitas literasi sangat berperan penting dalam kemajuan suatu bangsa 
1421 Sosialisasi Pentingnya Menumbuhkan Minat Baca di SD Negeri 236 Rumpala II Sinjai Barat Nasrullah, Irvan Muliyadi, Touku Umar, Agus Dermawan

DOI: https://doi.org/10.31004/abdidas.v2i6.490

(Musyarafah, 2018).

Upaya yang dilakukan pemerintah dalam meningkatkan minat dan kebiasaan membaca masyarakat sebenarnya telah dilakukan dengan berbagai cara. Pada tahun 2013 Direktorat pendidikan Masyarakat menyediakan layanan pendidikan masyarakat antara lain: Pendidikan keaksaraan, Pendidikan kecakapan hidup dan kewirausahaan, Pengembangan minat dan budaya baca Masyarakat, Penyesetaraan gender dan pendidikan perempuan, Pendidikan keorangtuaan, dan penataan kelembagaan Pendidikan Nasional (Munir \& Hidayatullah, 2019).

Sekolah Dasar Negeri 236 Rumpala II Sinjai Barat merupakan sekolah dasar negeri yang terletak di Kabupaten Sinjai Provinsi Sulawesi Selatan. Pada observasi awal yang dilakukan, pihak sekolah mengatakan bahwa minat baca siswa sangat kurang serta bahan bacaan yang terbatas dan kemampuan pengelola perpustakaan juga masih kurang karena adanya beberapa kendala.

Berdasarkan latar belakang diatas maka perlu adanya sosialisasi pentingnya meningkatkan minat baca pada siswa di SD Negeri 236 Rumpala II Sinjai Barat. Oleh karena itu jurusan Ilmu Perpustakaan Universitas Islam Negeri Alauddin Makassar mengadakan kegiatan Pengabdian Kepada Masyarakat (PKM) sebagai bentuk kewajiban dalam menjalankan Tri Dharma Perguruan Tinggi. Pada kegiatan pengadian ini bertujuan untuk memberikan pemahaman kepada siswa SD Negeri 236 Rumpala II Sinjai Barat betapa pentingnya menignkatkan minat baca serta memberikan pemahaman kepada pihak sekolah untuk mengoptimalkan fungsi perpustakaan yang sesuai Standar Nasional Perpustakaan Sekolah.

\section{METODE}

Kegiatan pengabdian masyarakat ini dilaksanakan pada hari Sabtu, tanggal 16 Oktober 2021 di SD Negeri 236 Rumpala II Sinjai Barat yang berlokasi di Kabupaten Sinjai Provinsi Sulawesi Selatan. Kegiatan ini melibatkan dosen jurusan ilmu perpustakaan, staf jurusan, pustakawan, guru dan siswa SD Negeri 236 Rumpala II Sinjai Barat.

Metode yang dilakukan pada kegiatan pengabdian masyarakat ini dilakukan dalam beberapa tahapan kegiatan sebagai berikut:

1. Memberikan bantuan koleksi bacaan. Pada kegiatan ini perwakilan Jurusan ilmu Perpustakan memberikan sumbangan koleksi bacaan kepada pihak SD Negeri 236 Rumpala II Sinjai Barat untuk menambah koleksi di Perpustakaannya.

2. Penyampaian Sosialisasi. Pada tahap ini salah satu perwakilan dosen memberikan ceramah atau sosialisasi tentang pentingnya minat baca.

3. Kunjungan dan pemantauan perpustakaan. Pada tahap ini dosen Jurusan Ilmu Perpustakaan mengunjungi dan memantau pengelolaan dan manajemen perpustakaan SD Negeri 236 Rumpala II Sinjai Barat.

\section{HASIL DAN PEMBAHASAN}


1422 Sosialisasi Pentingnya Menumbuhkan Minat Baca di SD Negeri 236 Rumpala II Sinjai Barat Nasrullah, Irvan Muliyadi, Touku Umar, Agus Dermawan

DOI: https://doi.org/10.31004/abdidas.v2i6.490

Pelaksanaan kegiatan pengabdian ini merupakan kegiatan rutinitas Jurusana Ilmu Perpustakaan setiap semester sebagai bentuk pengaplikasian ilmu pengetahuan kepada masyarakat dan merupakan kewajiban Tri Dharma pendidikan. Sebelum melaksanakan pengabdian ini, Jurusan Ilmu Perpustakaan kemudian menyusun kepanitian dalam rangka pengabdian masyarakat di SD Negeri 236 Rumpala II Sinjai Barat, selanjutnya melakukan survei dan permohonan izin kepada pihak SD Negeri 236 Rumpala II Sinjai Barat untuk melaksanakan kegiatan pengabdian kepada masyarakat sekaligus meninjau apa saja yang akan dibutuhkan didalam kegiatan pengabdian, kemudian berkordinasi dengan pimpinan fakultas untuk menyiapkan sarana dan prasarana pendukung kegiatan pengabdian, seperti menyiapkan kendaraan, narasumber, komsumsi dan peralatan yang terkait dalam kegiatan pengabdian masyarakat tersebut.

Pelaksanaan kegiatan pengabdian kepada masyarakat ini berlangsung selama 1 hari pada hari sabtu 16 Oktober 2021 bertempat di SD Negeri 236 Rumpala II Sinjai Barat Kabupaten Sinjai Provinsi Sulawesi Selatan. Kegiatan pengabdian ini dihadiri oleh perwakilan siswa, guru, pembina dan SD Negeri 236 Rumpala II Sinjai Barat.

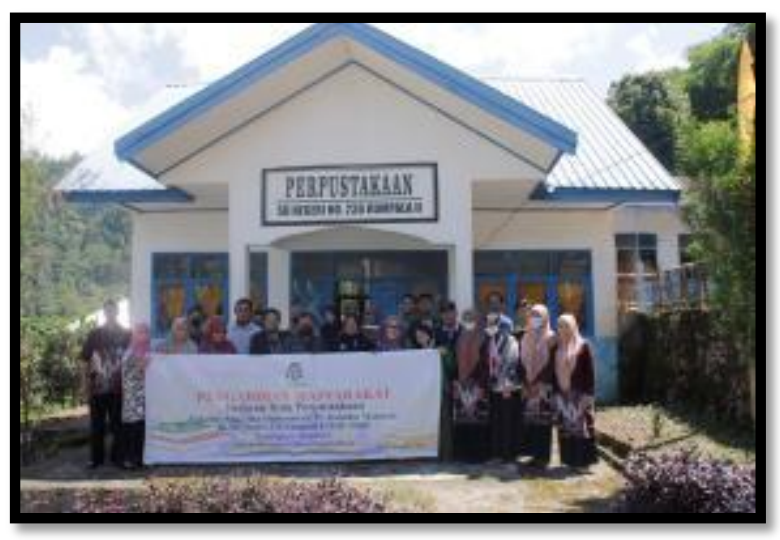

Gambar 1. Tim Pengabdian Masyarakat

Diawal pelaksanaan kegiatan pengabdian masyarakat terlebih dahulu dilaksanakan acara pembukaan yang dilaksanakan di salah satu ruangan kelas SD Negeri 236 Rumpala II Sinjai Barat. Pada acara pembukaan tersebut Pimpinan SD Negeri 236 Rumpala II Sinjai Barat memberikan sambutan selamat datang kepada tim pengabdian masyarakat yang telah hadir untuk memberikan pengetahuan dan wawasan baru di SD Negeri 236 Rumpala II Sinjai Barat. Pada sambutan pimpinan SD Negeri 236 Rumpala II Sinjai Barat merespon baik dengan adanya kegiatan pengabdian Jurusan Ilmu Perpustakaan ke SD Negeri 236 Rumpala II Sinjai Barat dan berharap kegiatan ini bukan hanya menjadi awal dan terakhir Jurusan Ilmu Perpustakaan berkunjung dan memberikan ilmu baru SD Negeri 236 Rumpala II Sinjai Barat tetapi terus berlanjut untuk kemajuan SD Negeri 236 Rumpala II Sinjai Barat.

Selanjutnya setelah pembukaan dilakukan penyerahan sumbangan koleksi bacaan kepada pihak sekolah yang diwakili oleh Ketua Jurusan Ilmu Perpustakaan Fakultas Adab dan Humaniora yakni Bapak Irvan Muliyadi, S.Ag., SS., MA dan 
1423 Sosialisasi Pentingnya Menumbuhkan Minat Baca di SD Negeri 236 Rumpala II Sinjai Barat Nasrullah, Irvan Muliyadi, Touku Umar, Agus Dermawan

DOI: https://doi.org/10.31004/abdidas.v2i6.490

diterima langsung oleh perwakilan SD Negeri 236

Rumpala II Sinjai Barat. Sumbangan koleksi bacaan ini diharapkan menjadi sumber informasi baru kepada semua civitas akademika SD Negeri 236 Rumpala II Sinjai Barat serta menjadi tambahan koleksi buku di perpustakaan. Sumbangan koleksi ini bertujuan agar koleksi perpustakaan tersebut update dalam menyediakan bahan bacaan kepada siswa, sehingga siswa tersebut tidak bosan dengan koleksi yang itu-itu saja dan bahkan akan semakin rajin mengunjungi perpustakaan.

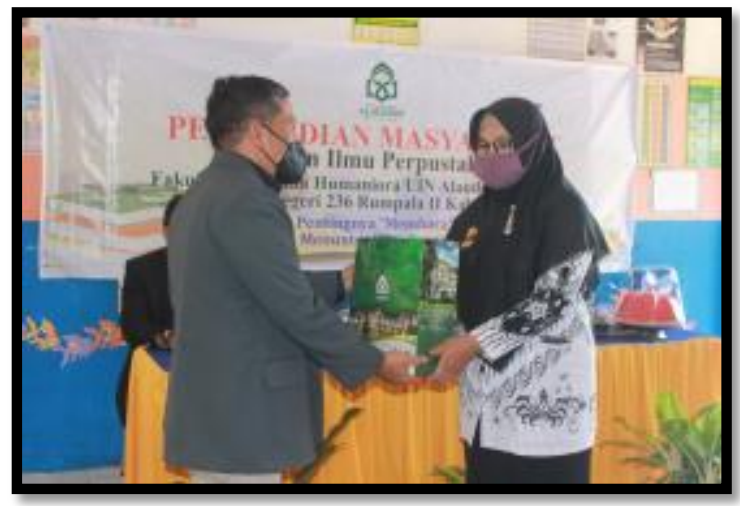

Gambar 2. Pemberian Sumbangan Koleksi Perpustakaan

Setelah dilakukan pemberian sumbangan buku kepada pihak SD Negeri 236 Rumpala II Sinjai Barat, kegiatan selanjurnya yakni sosialisasi pentingnya meningkatkan minat baca oleh Ibu Sitti Husaebah Pattah, S. Ag., SS., M. Hum yang juga sebagai dosen tetap Jurusan Ilmu Perpustakaan. Sosialisasi ini dilaksanakan di dalam kelas. Sosialisasi ini menggunakan metode ceramah, dengan menyampaikan materi didepan para siswa. Dalam penyampaian sosialisasi, pemateri memulai dengan menjelaskan tentang ayat pertama turun dalam Al-Quran surat Al Alaq ayat 1-5. Pada ayat tersebut dimulai dengan kata "Iqra" yang artinya bacalah, perintah membaca dalam Al-quran tersebut menjadi dasar kita untuk lebih dapat mudah mengetahui segala hal melalui dengan membaca. Materi dilanjutkan dengan memaparkan betapa pentingnya membaca dalam kehidupan bermasyarakat, apalagi dengan perkembangan zaman sekarang siapa yang menguasai informasi maka dia akan menguasai dunia, menguasai informasi ibarat memiliki kekuatan yang besar dalam menghadapi era persaingan dimana yang memiliki kualitas yang baiklah yang akan menang dibandingkan orang yang miskin informasi yang tentunya akan mengalami ketertinggalan atau lemah dalam menghadapi sebuah persaingan.

Pemateri juga menekankan untuk lebih cerdas dalam menggunakan internet, karena sebagaimana kita ketahui kemajuan teknologi internet sudah merubah kondisi sosial masyarakat. Kondisi yang dimaksud yakni dengan adanya internet bisa memudahkan seseorang dalam berkomunikasi, belajar dan bahkan berbelanja. Penggunaan internet juga tentu memiliki dampak negatif yang tentunya sangat meresahkan, seperti banyaknya berita atau informasi hoaks yang beredar di media sosial yang mampu memberikan pemahaman yang salah bahkan informasi hoaks ini dapat memecah belah persatuan dan kesatuan jika semakin tersebar. Maka dengan adanya penyuluhan ini diharapkan siswa dapat meningkatkan minat bacanya serta cerdas dalam mengolah dan memilah informasi yang beredar di internet, sehingga akan memunculkan generasigenerasi yang cerdas, sehat, sopan dan beretika 
1424 Sosialisasi Pentingnya Menumbuhkan Minat Baca di SD Negeri 236 Rumpala II Sinjai Barat Nasrullah, Irvan Muliyadi, Touku Umar, Agus Dermawan

DOI: https://doi.org/10.31004/abdidas.v2i6.490

dalam berselanjar di dunia maya. Setelah penyampaian materi kemudian dibuka sesi tanya jawab dengan para peserta, Terlihat antusias siswa dalam memberikan pertanyaan kepada pemateri

Pada sosialisasi ini, pemateri memperkenalkan beberapa alternatif yang bisa dilakukan pengelola perpustakaan untuk memberikan sumber informasi kepada peserta didik. Seperti aplikasi e-book IPusnas dari Perpustakaan Nasional, Buku Sekolah Elektronik dari Kementrian Pendidikan dan Kebudayaan yang bisa diakses secara gratis dan bisa didownload. Pemateri juga memperkenalkan Slims dan Inlis Lite sebagai aplikasi manajemen perpustakaan berbasis online yang memudahkan dalam mengelola koleksi mulai dari penginputan data buku, katalog, klasifikasi, pengembalian dan peminjaman buku yang dilakukan dengan teknologi.

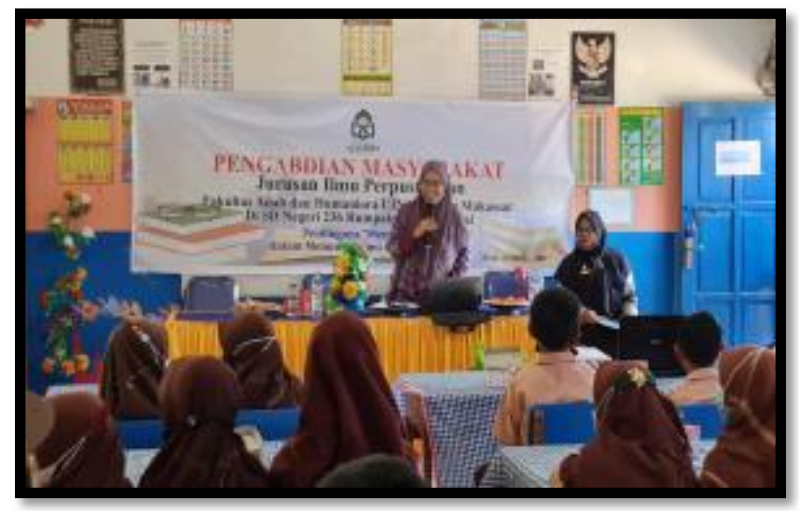

Gambar 3. Penyuluhan Minat Baca

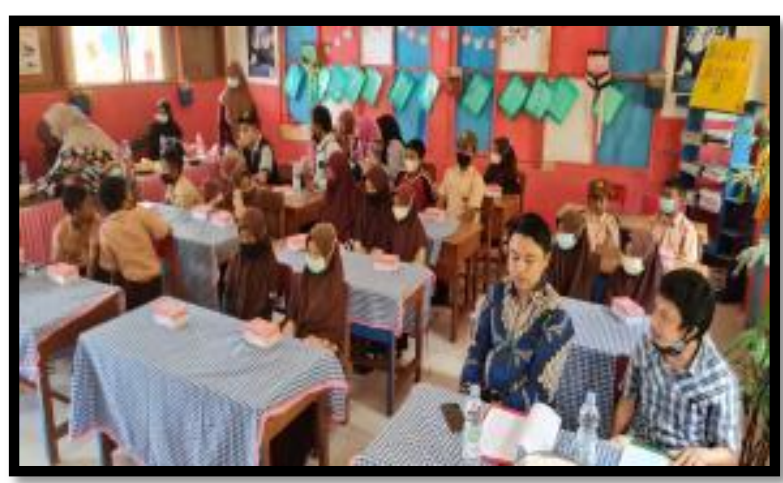

Gambar 4. Peserta Sosialisasi

Selanjutnya, tim pengabdian masyarakat Jurusan Ilmu Perpustakaan menuju ke perpustakaan SD Negeri 236 Rumpala II Sinjai Barat untuk melakukan peninjauan dan pembinaan pengelolaan perpustakaan sekolah yang baik sesuai Standar Nasional Perpustakaan (SNP). Pada hasil observasi yang dilakukan tim pengabdian jurusan Ilmu Perpustakaan menemukan masih adanya kekuranga yang diterapkan oleh pengelola perpustakaan SD Negeri 236 Rumpala II Sinjai Barat, seperti kesalahan dalam membuat katalog buku, mengklasifikasi jenis buku serta pengelolaan perpustakaan belum menggunakan sistem computer dalam pengelolaan perpustakaan dan masih menggunakan sistem manual.

Tim pengabdian masyarakat kemudian melakukan pembinaan dengan memberikan masukan dan arahan kepada pustakawan tentang bagaimana mengelola perpustakaan sekolah yang sesuai Standar Nasional Perpustakaan (SNP) yang telah dikeluarkan oleh Perpustakaan Nasional. Satu persatu tim pengabdian masyarakat memberikan bimbingan dan masukan terkait kekurangan yang ditemukan di perpustakaan, kemudian pustakawan mencatat segala masukan 
1425 Sosialisasi Pentingnya Menumbuhkan Minat Baca di SD Negeri 236 Rumpala II Sinjai Barat Nasrullah, Irvan Muliyadi, Touku Umar, Agus Dermawan

DOI: https://doi.org/10.31004/abdidas.v2i6.490

kemudian mengajukan pertanyaan jika ada hal yang belum dipahami.

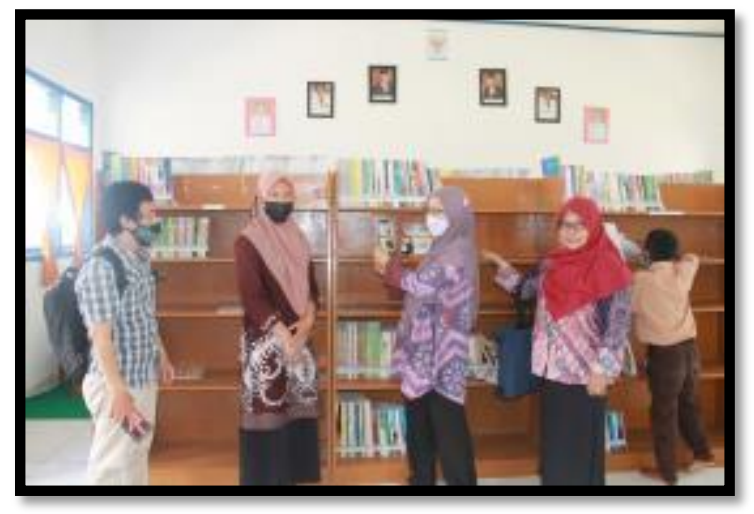

Gambar 5. Suasana Perpustakaan SD Negeri 236 Rumpala II Sinjai Barat

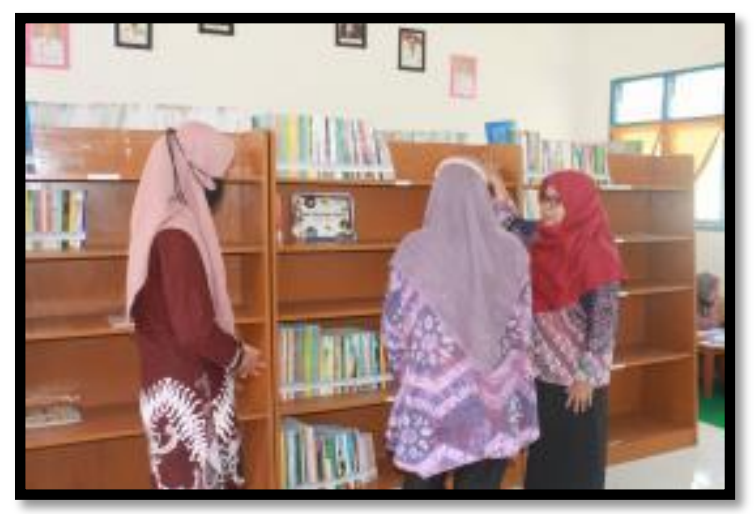

Gambar 6. Pembinaan Pustakawan SD Negeri 236 Rumpala II Sinjai Barat

\section{SIMPULAN}

Membaca merupakan kegiatan proses memahami isi teks dengan bersuara atau dalam hati dan juga untuk menemukan berbagai informasi yang terdapat dalam tulisan. Kegiatan proses membaca menjadi salah satu jenis kemampuan berbahasa melalui tulisasn yang bersifat reseptif karena dengan membaca seseorang akan memperoleh informasi, ilmu pengetahuan, dan pengalaman-pengalaman baru yang belum diketahui sebelumnya. Semua yang diperoleh melalui bacaan tersebut akan membuat seseorang mampu mempertinggi daya pikirannya, dan memperlu wawasan seseorang. Oleh karena itu membaca sangat penting bagi setiap orang, namun di indonesia minat baca tersebut masih sangat rendah.

Membaca merupakan salah satu upaya yang sangat penting dalam proses belajar mengajar. Membaca merupakan salah satu langkah yang sangat menentukan berhasil atau tidaknya proses belajar mengajar yang diharapkan. Dengan membaca berarti kita menerjemahkan, menginterprestasikan tanda-tanda atau lambanglambang dalam bahasa yang dipahami oleh pembaca. Konsep pendidikan yang dianut di negara kita adalah konsep pendidikan sepanjang hayat (life long education). Hal ini sejalan dengan kewajiban setiap manusia untuk selalu belajar sejak dilahirkan sampai akhir hayatnya.

Pemahaman tentang pentingnya membangun budaya baca pada siswa ini merupakan sesuatu hal yang sangat penting dilakukan, karena dengan adanya pemahaman lebih awal tentang apa manfaat membaca dan kelebihan jika seseorang memiliki wawasan yang luas, ini tentu akan lebih menguatkan pondasi anak untuk lebih rajin membaca sejak dini. Dengan adanya kegiatan pengabdian ini diharapkan siswa SD Negeri 236 Rumpala II Sinjai Barat lebih memahami pentingnya membaca serta pustakawan juga mampu mengelola perpustakaan dengan baik sehingga siswa lebih senang berkunjung ke perpustakaan. Serta semoga dengan adanya kegiatan pengadian ini pimpinan SD Negeri 236 Rumpala II Sinjai Barat lebih memperhatikan 
1426 Sosialisasi Pentingnya Menumbuhkan Minat Baca di SD Negeri 236 Rumpala II Sinjai Barat Nasrullah, Irvan Muliyadi, Touku Umar, Agus Dermawan

DOI: https://doi.org/10.31004/abdidas.v2i6.490

perpustakaan dalam hal penyediaan anggaran supaya perpustakaan tersebut tidak lagi menggunakan system konvensional namun dengan adanya anggaran yang memadai sehingga bisa menggunakan sistem otomasi digital.

\section{UCAPAN TERIMA KASIH}

Penulis mengucapkan terimakasih dan apresiasi yang setinggi-tingginya kepada pimpinan SD Negeri 236 Rumpala II Sinjai Barat yang telah memberikan kami izin untuk menjadi mitra dalam kegiatan Pengabdian Kepada Masyarakat. Penulis juga menyampaikan ucapan terimakasih kepada pimpinan Fakultas dan Jurusan yang telah mendanai kegiatan ini.

\section{DAFTAR PUSTAKA}

Kurniasari, L., \& Arfa, M. (2020). Peran Komunitas "Pustaka Sarwaga" dalam Membentuk Kemampuan Literasi Dini di Kota Semarang. Jurnal Ilmu Perpustakaan, 9(1).

Maharani, O. D. (2017). Minat Baca Anak-Anak Di Kampoeng Baca Kabupaten Jember. Jurnal Review Pendidikan Dasar: Jurnal Kajian Pendidikan Dan Hasil Penelitian, 3(1).

Maulana, A., \& Dkk. (2019). Peran Rumah Baca "Ceger Membara" Dalam Minat Baca di Desa Ceger, Jurang Mangu Barat. Prosiding Seminar Nasional Pengabdian Masyarakat LPPM UMJ.

Monica, A. R. (2020). Peran Komunitas Literasi Perpus Rakyat Dalam Upaya Meningkatkan Minat Baca Masyarakat Kota Jamb.

Munir, S., \& Hidayatullah, A. (2019). Peran Taman Bacaan Masyarakat (TBM) dalam Meningkatkan Minat dan Budaya Baca di Kabupaten Ciamis. Literasi : Jurnal Bahasa Dan Sastra Indonesia Serta Pembelajarannya, 3(1).
Musyarafah, U. S. (2018). Peran Komunitas Literasi dalam meningkatkan minat baca Masyarakat Desa: Studi Kasus di Taman

Bacaan Masyarakat Lumbung Ilmu Komunitas Literasi di Jalan Cibeureum Goalpara Kampung Babakan Peuntas Desa Sukaraja Kabupaten Sukabumi).

Nasrullah. (2020). Penerapan Gerakan Literasi Sekolah Dalam Meningkatkan Budaya Literasi Siswa SMP Dan SMA di Bosowa School Makassar. Jurnal Nalar Pendidikan, 8(1), 73-80. https://www.ojs.unm.ac.id/nalar/article/view/ $73-80 / 8254$ 